\title{
異なる関節角度における等尺性収縮時の膝伸展筋群 および膝蓋腱の形状変化特性
}

\author{
Mechanical Characteristics of the Knee Extensor Muscles and Patellar Tendon under \\ Isometric Contraction at Different Joint Angles
}

\author{
田中 重陽 ${ }^{1)}$ 今若 太郎 ${ }^{2)}$ 角田 直也 ${ }^{2)}$ \\ Shigeharu TANAKA, MS ${ }^{1)}$, TARO IMAWAKA, $\mathrm{MS}^{2)}$, NAOYA TSUNODA, $\mathrm{PhD}^{2)}$ \\ ${ }^{1)}$ Faculty of Political Science and Economics, Kokushikan University: 4-28-1 Setagaya, Setagaya-ku, Tokyo 154-8515, Japan \\ TEL+81 3-5451-8175 E-mail: sgtanaka@kokushikan.ac.jp \\ ${ }^{2)}$ Graduate School of Sport System, Kokushikan University
}

Rigakuryoho Kagaku 34(1): 89-96, 2019. Submitted Aug. 7, 2018. Accepted Sep. 21, 2018.

\begin{abstract}
Purpose] The purpose of this study was to clarify the mechanical characteristics of the knee extensor muscles and the patellar tendon during isometric contraction at different knee and hip joint angles. [Participants and Methods] The subjects were 11 healthy males. The knee extensor torque during isometric contraction was measured using a dynamometer. The degree of deformation as a mechanical activity was measured by a muscle contraction (MC) sensor. [Results] The knee extensor muscle showed a significantly higher degree of deformation when the knee joint was extended rather than flexed. However, the degree of deformation of the patellar tendon was significantly lower in knee extension than in knee flexion. [Conclusion] These results show that the degree of deformation measured using a MC sensor is influenced by deformation of the knee extensor muscles and the patellar tendon due to change in the knee joint angle.
\end{abstract}

Key words: knee extensor muscle, patellar tendon, MC sensor method

要旨：〔目的〕本研究では MC センサー法を用いて異なる関節角度における等尺性収縮時の膝伸展筋群および膝蓋腱

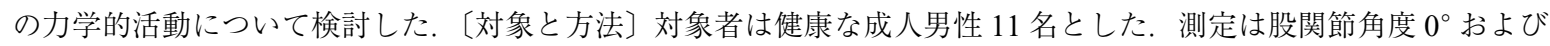
$90^{\circ}$, 膝関節角度 $30^{\circ}$ おび $90^{\circ}$ を組み合わせた 4 つ姿勢で行った，内側広筋斜頭，外側広筋，大腿直筋および膝 蓋腱の形状変化量は MC センサー法により計測した。〔結果〕膝伸展筋群の形状変化量は, 膝関節および股関節角度 の影響を受けるが，その影響は各筋によって異なった，膝蓋腱の形状変化量は滕関節 $30^{\circ} よ り も 90^{\circ}$ が有意に高い值 を示した。〔結語〕MC センサー法で計測した形状変化量は, 筋㧍よび腱の活動動態を評価する指標として活用でき る可能性が示唆された.

キーワード : 膝伸展笳群, 膝蓋腱, $\mathrm{MC}$ センサー法

\footnotetext{
1) 国士舘大学 政経学部：東京都世田谷区世田谷4-28-1 ( ⿳ 154-8515) TEL 03-5451-8175

2) 国士舘大学大学院 スポーツ・システム研究科

受付日 2018 年 8 月 7 日 受理日 2018 年 9 月 21 日
} 


\section{I.はじめに}

ヒトの身体運動は骨格筋の収縮によって生み出された 張力が, 腱を介して関節運動を引き起こすことで生じ る。そのため，筋の収縮特性とともに腱の活動特性を理 解することは，身体運動のメカニズムを探るうえで重要 である。これまでに腱の力学的特性は，超音波法によっ て評価されてきた。膝蓋腱は粘弾性組織 1)であり，筋 張力と密接な関係 ${ }^{2)}$ にあることが知られている。 また,

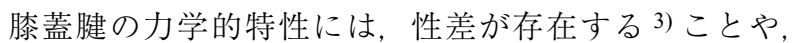
関節角度 ${ }^{4)}$, トレーニングの負荷強度 5,6 お およ゙筋収縮 様式 $5,7,8)$ によて異なることが報告されている.

一方で, 腱の力学的特性は対象や分析法によって異な るという指摘 9) があり, 膝関節の複雑な構造や機能を 定量化することは難しいものと考えられる．等尺性条件 下での膝伸展筋力の最大值は, 股関節角度が一定の場合, 膝関節角度 $50 \sim 90^{\circ}$ 屈曲位で認められることが報告 ${ }^{10)}$ されている。これは膝伸展筋群の筋放電量の大小や，筋 は筋節長の変化に応じた張力を発揮するという力 - 長さ 関係に依存したものである10-12)。複数の関節角度にお ける筋活動動態についての報告は比較的多くみられるも のの, 膝蓋腱の力学的特性に関する報告は, 股関節およ び膝関節ともに屈曲位で評価されたものが多い. 関節角 度の変化が筋および腱の力学的活動に及ぼす影響に関し ては十分な検討がなされていない.

近年，筋および腱の力学的活動を評価するために Muscle contraction sensor（MC センサー）法が開発され た ${ }^{13)}$ ，MC センサー法は，筋収縮によって筋や腱の形 状が変化した際の皮膚表面の張力を計測するという原理 に基づいており，対象とする筋や腱上の皮膚表面に，凸 状のチップを取り付けたセンサーを貼付することで, チップの先端に圧力が生じ, その圧力をセンサーに内蔵 されたストレインゲージで計測することができる。 Đorđević ら 13,14) は, MC センサー法によって等尺性肘 屈曲運動中の上腕二頭筋の張力を計測した。 その結果, 上腕二頭筋の張力と肘屈曲筋力との間には有意な相関関 係が認められ，得られた相関係数が極めて高いことを報 告している。またMohamadら 15) は, 大腿直筋を対象 に電気刺激による筋収縮時の張力を計測したところ，卜 ルクとの間に有意な相関関係が認められたことを明らか にした。ささらにĐorđevićらら16)は，同手法によって，ス クワット動作中の膝蓋腱および大腿四頭筋腱の張力を計 測し，それは膝関節の角度やトルクとの間にそれぞれ有 意な相関関係が認められることを報告している。これら の結果は, MC センサー法で計測した張力が，筋力レベ ルを反映する力学的指標になりうることを示すものであ る、しかしながら，MCセンサー法を用いた実験データ は上述のものに限られており，あらゆる筋長条件下にお ける随意収縮中の膝伸展筋群や腱の活動動態について検
討したものは見当たらない

そこで本研究では，MCセンサー法を用いて筋が収縮 した条件および伸張した条件下における等尺性収縮時の 膝伸展筋群および膝蓋腱の力学的活動の特徵について検 討することを目的とした。

\section{II. 対象と方法}

1. 対象

本研究の対象は股関節および膝関節に障害経験のない 成人男性 11 名とした，対象者の身体的特性は，年齢が $25.5 \pm 1.5$ 歳, 身長が $175.4 \pm 2.4 \mathrm{~cm}$, 体重 $70.3 \pm 2.8$ $\mathrm{kg}$, 体脂肪率が $14.8 \pm 1.4 \%$ (平均 \pm 標準偏差) であっ た. 全対象者に対して, 研究の目的, 実験方法およびそ の安全性について説明し，参加の同意を得た。なお，本 研究は国士舘大学倫理委員会の, 人を対象とした研究に 関する倫理審査の承認を受けた後に実施した（受付番 号：28-28).

2. 方法

対象者を総合筋力測定装置（Biodex System3, Biodex 社製）の椅子に座らせた。測定姿勢は，股関節角度を屈 曲伸展 $0^{\circ}$ ( 以下, $\mathrm{H} 0^{\circ}$ ) および $90^{\circ}$ 屈曲位（以下, $\left.\mathrm{H} 90^{\circ}\right)$ に設定し，膝関節角度を $30^{\circ}$ (以下， K $30^{\circ}$ ） お よび $90^{\circ}$ (以下, $\mathrm{K} 90^{\circ}$ ) 屈曲位（完全伸展位を $0^{\circ}$ ) と した，対象者には股関節および膝関節角度の組み合わせ による計 4 つの姿勢で測定を実施した（図 1).

膝蓋腱の形状は, 超音波診断装置（SSD-900, ALOKA 社製) のB モード法（7.5 Hz）を用いて測定し た。対象者が各測定姿勢において安静状態を保った状態 で，膝蓋骨，膝蓋腱および脛骨が写るようにプローブを 押し当て, 縦断画像を撮影した. 得られた超音波画像か ら，画像処理プログラム（ImageJ）を用いて膝蓋腱の 長さ，厚さおよび撓み（湾曲角度）を計測した。滕蓋腱 長は先行研究 7) を参考とし, 膝蓋骨の遠位端と脛骨結 節との間の距離を計測した。また, 先行研究 17)に倣い, 膝蓋骨の遠位端，膝蓋腱長の $25 \% ， 50 \% ， 75 \%$ および

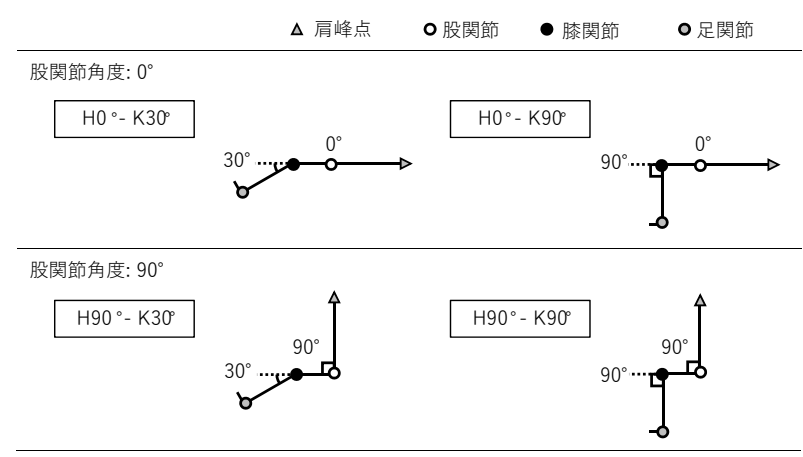

図1 測定姿勢の定義 
脛骨結節の 5 箇所の地点の厚さを計測し, その平均值を 膝蓋腱の厚さとした。膝蓋腱の撓みは，膝蓋骨の遠位端， 脛骨結節および最も湾曲した点の 3 点を結び, その角度 を計測した。

等尺性膝伸展卜ルクは, 総合筋力測定装置のダイナモ メーターを用いて測定した。トルクの発揮方法は，筋お よび腱への急激な負担と, 後述する筋放電量の測定にお ける電気力学的遅延を考慮し, 測定開始から 10 秒間で 漸増的に増加させるように指示し，その後 3 秒間は最大 努力でのトルク発揮を維持させた。試技間には十分な休 息を挟み，疲労の影響がないよう配慮した４つの測定 姿勢における測定順序は対象者によってランダムとした。

筋放電量の測定は無線型筋電計 (多チャンネルテレ メーターシステム WEB 1000 , 日本光電社製）により, 総合筋力測定装置と同期して実施した。測定対象の筋は, 右脚の内側広筋斜頭 (以下, VMO), 外側広筋 (以下, VL) および大腿直筋（以下， RF）とした。電極貼付位 置は, 先行研究 18) を参考とし, VMO は膝蓋骨底から 約 $4 \mathrm{~cm}$ 近位, $\mathrm{VL}$ は膝蓋骨底から $8 \sim 10 \mathrm{~cm}$ 近位, $\mathrm{RF}$ は大腿長の $50 \%$ の筋腹部位とした。電極を貼付する際 は, 皮膚と電極間の抵抗を最小にするために苟毛処理を
施し, 超音波診断装置を用いて筋の形状を入念に確認し ながら，他筋からのクロストークの影響がないよう配慮 した。

筋および腱の形状変化量は, Đorđević ら 13)の手法を 参考に MC センサー（TMG-BMC 社製）を用いて測定 した，測定対象の筋は筋放電量の測定と同じ 3 筋と滕蓋 腱（以下, PT）とした。膝蓋腱は，超音波診断装置に より膝蓋腱の中央部を確認した後に貼付した。 センサー 貼付の際は，筋電図電極と接触しないように配慮した。 その後, センサーをキネシオテープで固定し, 測定終了 まで剥がさないようにした。

MC センサーは, カーボン繊維で作られた楕円型のサ ポートパッド $(40 \times 25 \mathrm{~mm})$ に, 舌状突起型のチップ を $5 \mathrm{~mm}$ 突出した状態で取り付け，対象とする筋や腱上 の皮膚表面に貼付することで, 筋収縮に伴う形状変化に よってチップに生じた圧力を, センサーに内蔵したスト レインゲージによって計測するものである. MC セン サーの測定原理は図 2 に示した。筋収縮によって筋およ び腱上の皮膚表面に沿った圧力（F）が生じ，この圧力 によって皮下脂肪組織および皮膚がチップを押し付け る. 全ての力の合力は, チップの鉛直方向に Fs を生成

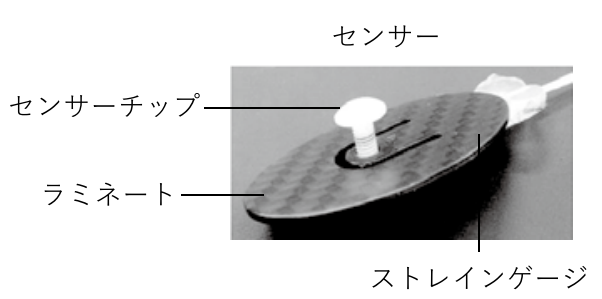

a. センサーの構造

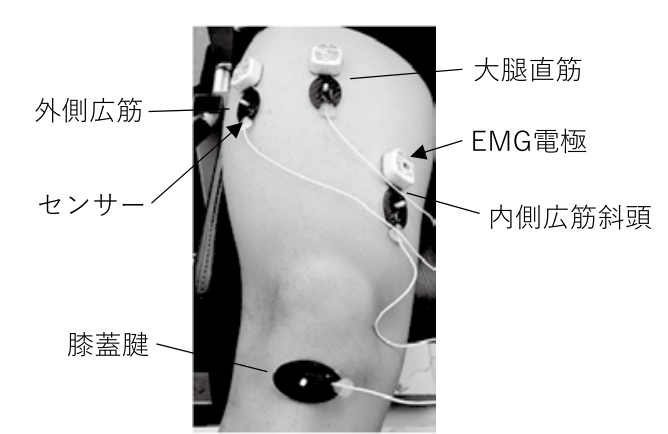

b. 測定部位
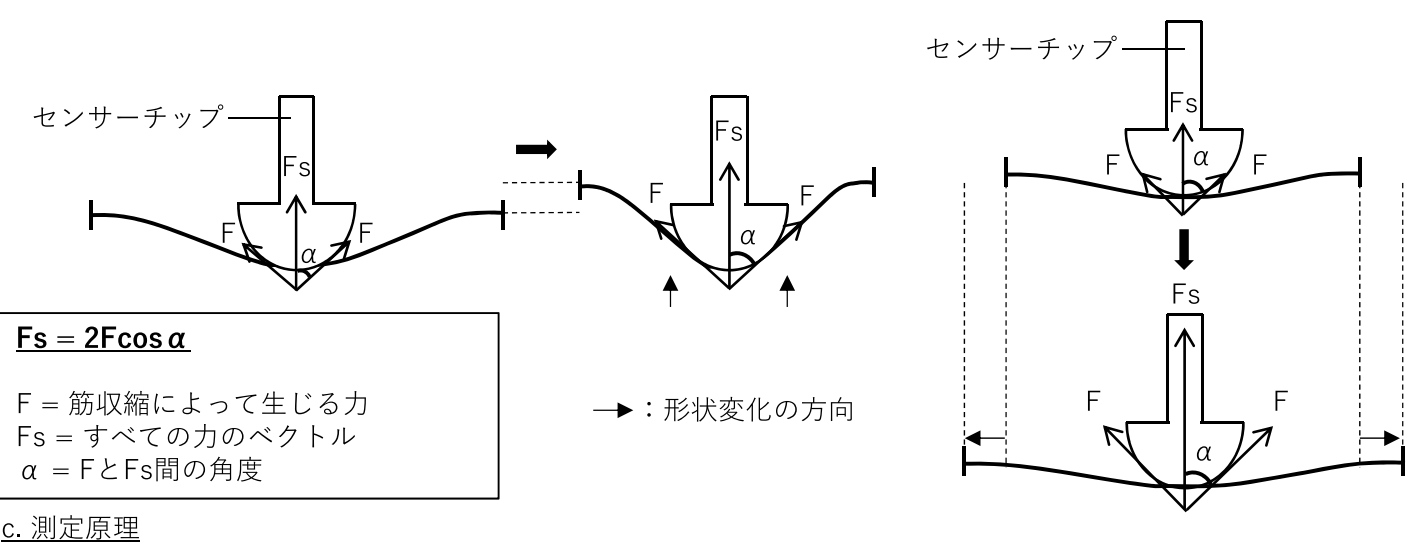

図2 MCセンサーの構造 (a), 測定部位 (b) および測定原理 (c)

(c) はMCセンサーの測定原理を模式図で示したものである。左図は, 筋収縮によって筋が膨隆した状態 を示し, 右図は, 左右方向に形状が変化(伸張)した状態を示したものである.

筋収縮時の筋および腱の形状変化によって測定部位上に沿った方向に力 $(\mathrm{F})$ が生じる。この力によって皮 下組織抢よび皮膚がセンサーチップ上に押し付けられる. 全ての力のベクトルの総和は, センサーチップに沿つ た方向に力 $(\mathrm{Fs})$ を生成する. Fs $=2 \mathrm{~F} \cos \alpha$ は測定原理の単純 $2 \mathrm{D}$ モデルを示す. 
する. チップにかかる圧力と鉛直方向に対する角度 $(\alpha)$ からその合力を, 以下の式によって求めるものである.

$$
\mathrm{Fs}=2 \mathrm{~F} \cos \alpha
$$

センサーの感度および較正は, Đorđević ら 13)によっ て報告されているように，6つの荷重により各センサー の感度（電圧）を計測し, 荷重と感度の関係から得られ る相関係数が 0.994〜0.999 であることが確認されてい る. 本研究で用いた 4 つのセンサーは, 先行研究 13) と 同仕様のものであり, 計測した值は, 各センサーの較正 式によって電圧から力 $(\mathrm{N})$ へと換算した。記録したデー タは, Sensmotionソフトウェアー（TMG-BMC 社製） を用いて分析した，得られるデータは，関節角度の変化 によって測定部位の筋厚および脂肪厚の变化による影響 が考えられるため, 安静状態においてセンサーを貼付し た際の值を初期值とし, 筋収縮中の值から初期值を差し 引いた差を形状変化量と定義し, 分析の対象とした。

トルク，筋放電量および形状変化量のデータは， A/D 変換解析プログラム (DASY-lab, AP-office 社製)によっ てPCに取り込んだ．全てのデータサンプリング周波数 は $1000 \mathrm{~Hz}$ であり，トルクおよび形状変化量のデー夕は, ローパスフィルター（2 Hzカットオフ）および 6 次ゼ ロラグバタワースフィルターを用いて処理した． EMG 信号は全波整流した後，10４00 Hzのバンドパスフィ ルター処理を行った。分析範囲は測定開始からピークト ルク発揮後の 1 秒までとし，ピークトルクに対する\% MVC を算出した。この\% MVCの算出区間に基づいて， 筋放電量および形状変化量の平均值をそれぞれ求めた。

統計処理は, SPSS Statistics version 25 (IBM 社製)
を用いて行った。まず，正規性の検定を実施し，全ての 変数が正規分布であることを確認した。膝蓋腱の形状お よびピークトルクは, 股関節角度と膝関節角度による 2 要因分散分析（対応あり・あり）を実施した，筋放電量 および形状変化量は, 股関節角度, 膝関節角度, トルク 強度の 3 要因による反復測定を実施し, 股関節角度 $\times$ 膝関節角度, 股関節角度 $\times$ トルク強度, 膝関節角度 $\times$ トルク強度のそれぞれの組合せによる分散分析（対応あ り・あり）を実施した。その後，交互作用が認められた 場合は, Post-hocテスト（Bonferroni）により主効果お よび単純主効果の検定を行い, 交互作用が認められな かった場合は多重比較検定を実施した。いずれも危険率 5\%をもって有意とした。

\section{III. 結 果}

膝蓋腱長および厚さは, 股関節角度および膝関節角度 による有意な差は認められなかった。一方，膝蓋腱の撓 みは，両関節角度による有意な交互作用は認められな かったが, 膝関節角度にのみ有意な主効果がみられた。 多重比較検定の結果, $\mathrm{H} 0^{\circ}$ および $\mathrm{H} 90^{\circ}$ ともに, K90 がK30॰よりも有意に高い值を示した（表 1 ）。

ピークトルクは，両関節角度による有意な交互作用が 認められた。関節ごとの単純主効果を検定した結果, 膝 関節角度による有意差が認められ, $\mathrm{H} 0^{\circ}$ および $\mathrm{H} 90^{\circ}$ と もに, K90がK30よりも有意に高い值を示した（表2).

筋放電量は，全ての筋において股関節角度 $\times$ 膝関節 角度による交互作用は認められなかったが，膝関節角度

表 1 各測定姿勢における安静時の滕蓋腱の長さ, 厚さおよび撓み

\begin{tabular}{lrrrrr}
\hline \multirow{2}{*}{ 測定項目 } & \multicolumn{3}{c}{$\mathrm{H} 0^{\circ}$} & & \multicolumn{2}{c}{${\mathrm{H} 90^{\circ}}^{\circ}$} \\
\cline { 2 - 3 } \cline { 5 - 6 } \cline { 5 - 6 } & \multicolumn{1}{c}{$\mathrm{K} 30^{\circ}$} & \multicolumn{1}{c}{$\mathrm{K} 90^{\circ}$} & & \multicolumn{1}{c}{$\mathrm{K} 30^{\circ}$} & $\mathrm{K} 90^{\circ}$ \\
\hline 長さ $(\mathrm{mm})$ & $43.4 \pm 4.3$ & $39.1 \pm 3.4$ & & $43.2 \pm 4.7$ & $40.8 \pm 3.6$ \\
厚さ $(\mathrm{mm})$ & $4.0 \pm 0.3$ & $3.7 \pm 0.4$ & & $3.9 \pm 0.4$ & $3.7 \pm 0.3$ \\
撓み $($ degree $)$ & $163.0 \pm 3.7$ & $170.3 \pm 3.1^{*}$ & & $162.0 \pm 4.3$ & $171.5 \pm 2.2^{*}$ \\
\hline
\end{tabular}

平均值 \pm 標準偏差. $\mathrm{H} 0^{\circ}$ : 股関節角度 $0^{\circ}, \mathrm{H} 90^{\circ}$ : 股関節角度 $90^{\circ}, \mathrm{K} 30^{\circ}$ : 膝関節角度 $30^{\circ}, \mathrm{K} 90^{\circ}$ : 膝関節角度 $90^{\circ}$. * : 同一股関節角度に打ける膝関節角度の違いによる有意 差 $(\mathrm{p}<0.05)$, 同一膝関節角度における股関節角度の有意差はなし.

表 2 各測定姿勢におけるピークトルクの比較

\begin{tabular}{|c|c|c|c|c|}
\hline \multirow{2}{*}{ 測定項目 } & \multicolumn{2}{|c|}{$\mathrm{H} 0^{\circ}$} & \multicolumn{2}{|c|}{$\mathrm{H} 90^{\circ}$} \\
\hline & $\mathrm{K} 30^{\circ}$ & $\mathrm{K} 90^{\circ}$ & $\mathrm{K} 30^{\circ}$ & $\mathrm{K} 90^{\circ}$ \\
\hline ピークトルク $(\mathrm{Nm})$ & $109.6 \pm 17.7$ & $186.4 \pm 50.3^{*}$ & $109.3 \pm 21.5$ & $206.9 \pm 58.7^{*}$ \\
\hline
\end{tabular}


×トルク強度による交互作用が認められ，VMO および $\mathrm{VL}$ では股関節角度 $\times$ トルク強度による交互作用が確 認された. 単純主効果および多重比較検定の結果, $\mathrm{VMO}$ の $\mathrm{H} 0$ ○では, $70 \% \mathrm{MVC}$ 以降, $\mathrm{H} 90 \circ$ では $100 \%$ MVCで, VLは $\mathrm{H} 0^{\circ}$ の $50 \% \mathrm{MVC}$ 以降, $\mathrm{H} 90^{\circ}$ の $70 \%$ MVC 以降でK90がK $30^{\circ}$ より有意に高い值を示した。 $\mathrm{RF}$ は, $\mathrm{H} 90^{\circ} の$ み膝関節角度の主効果が確認され, 単純 主効果検定の結果, $50 \% \mathrm{MVC}$ 以降で $\mathrm{K} 90^{\circ}$ が $\mathrm{K} 30^{\circ}$ よ りも有意に高い值を示した（表 3 ）.

各測定姿勢における形状変化量を表 4 に示した。 $\mathrm{VMO}$ は，股関節角度 $\times$ トルク強度による交互作用が認 められたが，股関節角度による主効果は確認されなかっ た. 多重比較検定の結果, $\mathrm{H} 0^{\circ}$ および $\mathrm{H} 90^{\circ}$ ともに $40 \%$ MVC 以降で K $30^{\circ}$ がK90。よりも有意に高い值を示した. VL は膝関節角度 $\times$ トク強度による交互作用が認めら
れ, $\mathrm{H} 0^{\circ}$ では $80 \% \mathrm{MVC}$ 以降, $\mathrm{H} 90^{\circ}$ では $60 \% \mathrm{MVC}$ 以 降で $\mathrm{K} 30^{\circ}$ と $\mathrm{K} 90^{\circ}$ の間に単純主効果の有意差を認めた。 RF は 2 要因の全ての組み合わせによる交互作用が認め られ，その後の検定結果， $\mathrm{H} 0^{\circ}$ では $70 \% \mathrm{MVC}$ 以降 $\mathrm{K} 90^{\circ}$ よりも $\mathrm{K} 30^{\circ}$ が有意に高く，30\% MVC〜60\% $\mathrm{MVC}$ の $\mathrm{K} 30^{\circ}$ では股関節角度間の有意差を認めた，PT の形状変化量は, 股関節角度 $\times$ トルク強度, 膝関節角 度 $\times$ トルク強度による交互作用が確認された，各水準 における主効果の検定の結果, 膝関節角度による有意差 が認められ, 多重比較検定の結果 $\mathrm{H} 0^{\circ}$ および $\mathrm{H} 90^{\circ}$ とも

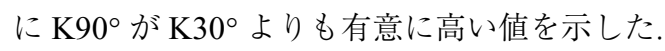

\section{IV. 考 察}

本研究では, MC センサー法を用いて異なる関節角度

表 3 各測定姿勢におけるトルクの増大に伴う筋放電量

\begin{tabular}{|c|c|c|c|c|c|}
\hline & \multirow{2}{*}{ トルク強度 } & \multicolumn{2}{|c|}{$\mathrm{H} 0^{\circ}$} & \multicolumn{2}{|c|}{$\mathrm{H} 90^{\circ}$} \\
\hline & & $\mathrm{K} 30^{\circ}$ & $\mathrm{K} 90^{\circ}$ & $\mathrm{K} 30^{\circ}$ & $\mathrm{K} 90^{\circ}$ \\
\hline \multirow{10}{*}{ EMG_VMO（mV） } & $10 \%$ & $0.005 \pm 0.003$ & $0.003 \pm 0.001$ & $0.002 \pm 0.000$ & $0.004 \pm 0.001$ \\
\hline & $20 \%$ & $0.007 \pm 0.002$ & $0.015 \pm 0.004$ & $0.007 \pm 0.002$ & $0.018 \pm 0.004$ \\
\hline & $30 \%$ & $0.013 \pm 0.003$ & $0.021 \pm 0.005$ & $0.011 \pm 0.004$ & $0.026 \pm 0.005$ \\
\hline & $40 \%$ & $0.018 \pm 0.005$ & $0.031 \pm 0.007$ & $0.017 \pm 0.005$ & $0.037 \pm 0.006$ \\
\hline & $50 \%$ & $0.023 \pm 0.006$ & $0.042 \pm 0.010$ & $0.029 \pm 0.010$ & $0.057 \pm 0.013$ \\
\hline & $60 \%$ & $0.030 \pm 0.006$ & $0.058 \pm 0.014$ & $0.041 \pm 0.015$ & $0.073 \pm 0.016$ \\
\hline & $70 \%$ & $0.042 \pm 0.012$ & $0.073 \pm 0.016^{*}$ & $0.047 \pm 0.012$ & $0.088 \pm 0.019$ \\
\hline & $80 \%$ & $0.060 \pm 0.018$ & $0.090 \pm 0.020^{*}$ & $0.069 \pm 0.018$ & $0.107 \pm 0.023$ \\
\hline & $90 \%$ & $0.076 \pm 0.018$ & $0.108 \pm 0.026^{*}$ & $0.085 \pm 0.020$ & $0.125 \pm 0.026$ \\
\hline & $100 \%$ & $0.085 \pm 0.016$ & $0.119 \pm 0.029^{*}$ & $0.090 \pm 0.020$ & $0.137 \pm 0.029^{*}$ \\
\hline \multirow{10}{*}{ EMG_VL（mV） } & $10 \%$ & $0.002 \pm 0.001$ & $0.004 \pm 0.002$ & $0.002 \pm 0.001$ & $0.004 \pm 0.001$ \\
\hline & $20 \%$ & $0.009 \pm 0.002$ & $0.018 \pm 0.003$ & $0.009 \pm 0.003$ & $0.020 \pm 0.004$ \\
\hline & $30 \%$ & $0.014 \pm 0.002$ & $0.026 \pm 0.004$ & $0.017 \pm 0.004$ & $0.027 \pm 0.014$ \\
\hline & $40 \%$ & $0.017 \pm 0.003$ & $0.034 \pm 0.005$ & $0.021 \pm 0.004$ & $0.034 \pm 0.005$ \\
\hline & $50 \%$ & $0.023 \pm 0.004$ & $0.044 \pm 0.006^{*}$ & $0.031 \pm 0.007$ & $0.050 \pm 0.008$ \\
\hline & $60 \%$ & $0.030 \pm 0.005$ & $0.052 \pm 0.008^{*}$ & $0.041 \pm 0.009$ & $0.058 \pm 0.009$ \\
\hline & $70 \%$ & $0.037 \pm 0.006$ & $0.059 \pm 0.008^{*}$ & $0.048 \pm 0.010$ & $0.072 \pm 0.011^{*}$ \\
\hline & $80 \%$ & $0.049 \pm 0.007$ & $0.073 \pm 0.012 *$ & $0.056 \pm 0.011$ & $0.083 \pm 0.012 *$ \\
\hline & $90 \%$ & $0.060 \pm 0.008$ & $0.083 \pm 0.013 *$ & $0.063 \pm 0.010$ & $0.093 \pm 0.013 *$ \\
\hline & $100 \%$ & $0.065 \pm 0.008$ & $0.091 \pm 0.014^{*}$ & $0.068 \pm 0.010$ & $0.108 \pm 0.015^{*}$ \\
\hline \multirow{10}{*}{ EMG_RF（mV） } & $10 \%$ & $0.003 \pm 0.001$ & $0.001 \pm 0.000$ & $0.002 \pm 0.000$ & $0.002 \pm 0.001$ \\
\hline & $20 \%$ & $0.007 \pm 0.001$ & $0.004 \pm 0.001$ & $0.006 \pm 0.002$ & $0.006 \pm 0.001$ \\
\hline & $30 \%$ & $0.012 \pm 0.002$ & $0.008 \pm 0.002$ & $0.008 \pm 0.002$ & $0.011 \pm 0.002$ \\
\hline & $40 \%$ & $0.019 \pm 0.003$ & $0.014 \pm 0.002$ & $0.011 \pm 0.002$ & $0.020 \pm 0.003$ \\
\hline & $50 \%$ & $0.025 \pm 0.002$ & $0.021 \pm 0.003$ & $0.015 \pm 0.003$ & $0.030 \pm 0.004^{*}$ \\
\hline & $60 \%$ & $0.033 \pm 0.003$ & $0.031 \pm 0.004$ & $0.020 \pm 0.003$ & $0.041 \pm 0.005^{*}$ \\
\hline & $70 \%$ & $0.041 \pm 0.003$ & $0.042 \pm 0.006$ & $0.026 \pm 0.003$ & $0.057 \pm 0.006^{*}$ \\
\hline & $80 \%$ & $0.057 \pm 0.008$ & $0.057 \pm 0.008$ & $0.038 \pm 0.004$ & $0.070 \pm 0.007^{*}$ \\
\hline & $90 \%$ & $0.072 \pm 0.009$ & $0.069 \pm 0.009$ & $0.052 \pm 0.006$ & $0.082 \pm 0.008^{*}$ \\
\hline & $100 \%$ & $0.086 \pm 0.010$ & $0.078 \pm 0.011$ & $0.067 \pm 0.007$ & $0.090 \pm 0.009^{*}$ \\
\hline
\end{tabular}

平均值 \pm 標準誤差. $\mathrm{H} 0^{\circ}$ : 股関節角度 $0^{\circ}, \mathrm{H} 90^{\circ}$ : 股関節角度 $90^{\circ}, \mathrm{K} 30^{\circ}$ : 膝関節角度 $30^{\circ}, \mathrm{K} 90^{\circ}$ : 膝関節角度 $90^{\circ}$. $\mathrm{EMG}$ : 筋電図, $\mathrm{VMO}$ : 内側広筋斜頭, $\mathrm{VL}$ : 外側広筋, $\mathrm{RF}$ ：大腿直筋。* : 同一股関節角度に扔ける膝関節角度の違い による有意差 $(\mathrm{p}<0.05)$, 同一膝関節角度における股関節角度の有意差はなし. 
表 4 各測定姿勢におけるトルクの増大に伴う形状変化量

\begin{tabular}{|c|c|c|c|c|c|}
\hline & \multirow{2}{*}{ トルク強度 } & \multicolumn{2}{|c|}{$\mathrm{H} 0^{\circ}$} & \multicolumn{2}{|c|}{$\mathrm{H} 90^{\circ}$} \\
\hline & & $\mathrm{K} 30^{\circ}$ & $\mathrm{K} 90^{\circ}$ & $\mathrm{K} 30^{\circ}$ & $\mathrm{K} 90^{\circ}$ \\
\hline \multirow{10}{*}{ MC_VMO (N) } & $10 \%$ & $0.030 \pm 0.007$ & $0.031 \pm 0.007$ & $0.030 \pm 0.009$ & $0.065 \pm 0.013$ \\
\hline & $20 \%$ & $0.233 \pm 0.043$ & $0.130 \pm 0.021$ & $0.169 \pm 0.037$ & $0.192 \pm 0.025$ \\
\hline & $30 \%$ & $0.398 \pm 0.073$ & $0.170 \pm 0.031$ & $0.326 \pm 0.059$ & $0.203 \pm 0.034$ \\
\hline & $40 \%$ & $0.517 \pm 0.085^{*}$ & $0.197 \pm 0.037$ & $0.481 \pm 0.086^{*}$ & $0.203 \pm 0.039$ \\
\hline & $50 \%$ & $0.621 \pm 0.091 *$ & $0.235 \pm 0.044$ & $0.642 \pm 0.118^{*}$ & $0.243 \pm 0.055$ \\
\hline & $60 \%$ & $0.723 \pm 0.106^{*}$ & $0.295 \pm 0.049$ & $0.771 \pm 0.143^{*}$ & $0.267 \pm 0.064$ \\
\hline & $70 \%$ & $0.841 \pm 0.123^{*}$ & $0.331 \pm 0.054$ & $0.877 \pm 0.162 *$ & $0.303 \pm 0.071$ \\
\hline & $80 \%$ & $0.958 \pm 0.143^{*}$ & $0.373 \pm 0.065$ & $0.982 \pm 0.171^{*}$ & $0.356 \pm 0.079$ \\
\hline & $90 \%$ & $1.031 \pm 0.152 *$ & $0.424 \pm 0.077$ & $1.071 \pm 0.181^{*}$ & $0.403 \pm 0.087$ \\
\hline & $100 \%$ & $1.064 \pm 0.151^{*}$ & $0.464 \pm 0.086$ & $1.129 \pm 0.190^{*}$ & $0.453 \pm 0.102$ \\
\hline \multirow{10}{*}{ MC_VL（N） } & $10 \%$ & $0.074 \pm 0.026$ & $0.088 \pm 0.014$ & $0.063 \pm 0.015$ & $0.123 \pm 0.032$ \\
\hline & $20 \%$ & $0.383 \pm 0.082$ & $0.514 \pm 0.104$ & $0.301 \pm 0.087$ & $0.203 \pm 0.053$ \\
\hline & $30 \%$ & $0.696 \pm 0.162$ & $0.662 \pm 0.151$ & $0.543 \pm 0.134$ & $0.265 \pm 0.082$ \\
\hline & $40 \%$ & $0.961 \pm 0.191$ & $0.778 \pm 0.192$ & $0.780 \pm 0.169$ & $0.362 \pm 0.087$ \\
\hline & $50 \%$ & $1.226 \pm 0.204$ & $0.868 \pm 0.208$ & $1.050 \pm 0.207$ & $0.500 \pm 0.106$ \\
\hline & $60 \%$ & $1.510 \pm 0.239$ & $1.033 \pm 0.245$ & $1.317 \pm 0.237^{*}$ & $0.658 \pm 0.132$ \\
\hline & $70 \%$ & $1.820 \pm 0.958$ & $1.188 \pm 0.285$ & $1.615 \pm 0.262 *$ & $0.881 \pm 0.161$ \\
\hline & $80 \%$ & $2.127 \pm 0.326^{*}$ & $1.360 \pm 0.347$ & $1.852 \pm 0.318^{*}$ & $1.108 \pm 0.197$ \\
\hline & $90 \%$ & $2.388 \pm 0.363^{*}$ & $1.520 \pm 0.399$ & $2.050 \pm 0.348^{*}$ & $1.323 \pm 0.247$ \\
\hline & $100 \%$ & $2.592 \pm 0.372 *$ & $1.686 \pm 0.455$ & $2.166 \pm 0.333^{*}$ & $1.512 \pm 0.292$ \\
\hline \multirow{10}{*}{ MC_RF（N） } & $10 \%$ & $0.041 \pm 0.016$ & $0.038 \pm 0.010$ & $0.035 \pm 0.007$ & $0.040 \pm 0.005$ \\
\hline & $20 \%$ & $0.140 \pm 0.040$ & $0.149 \pm 0.040$ & $0.070 \pm 0.028$ & $0.099 \pm 0.022$ \\
\hline & $30 \%$ & $0.271 \pm 0.049^{\#}$ & $0.246 \pm 0.048$ & $0.110 \pm 0.036$ & $0.217 \pm 0.037$ \\
\hline & $40 \%$ & $0.484 \pm 0.079^{\#}$ & $0.323 \pm 0.044$ & $0.181 \pm 0.059$ & $0.344 \pm 0.056$ \\
\hline & $50 \%$ & $0.631 \pm 0.096^{\#}$ & $0.378 \pm 0.054$ & $0.273 \pm 0.081$ & $0.406 \pm 0.069$ \\
\hline & $60 \%$ & $0.748 \pm 0.112^{\#}$ & $0.440 \pm 0.078$ & $0.456 \pm 0.112$ & $0.494 \pm 0.088$ \\
\hline & $70 \%$ & $0.861 \pm 0.134 *$ & $0.507 \pm 0.100$ & $0.620 \pm 0.139$ & $0.601 \pm 0.120$ \\
\hline & $80 \%$ & $1.030 \pm 0.199 *$ & $0.583 \pm 0.128$ & $0.780 \pm 0.154$ & $0.705 \pm 0.149$ \\
\hline & $90 \%$ & $1.170 \pm 0.212 *$ & $0.642 \pm 0.139$ & $0.938 \pm 0.170$ & $0.808 \pm 0.185$ \\
\hline & $100 \%$ & $1.293 \pm 0.234 *$ & $0.676 \pm 0.158$ & $1.144 \pm 0.202$ & $0.858 \pm 0.202^{\#}$ \\
\hline \multirow{10}{*}{ MC_PT（N） } & $10 \%$ & $0.166 \pm 0.075$ & $0.217 \pm 0.045$ & $0.140 \pm 0.040$ & $0.290 \pm 0.061$ \\
\hline & $20 \%$ & $0.361 \pm 0.072$ & $0.657 \pm 0.140 *$ & $0.288 \pm 0.054$ & $0.641 \pm 0.162^{*}$ \\
\hline & $30 \%$ & $0.315 \pm 0.064$ & $0.556 \pm 0.118^{*}$ & $0.234 \pm 0.045$ & $0.469 \pm 0.120^{*}$ \\
\hline & $40 \%$ & $0.301 \pm 0.061$ & $0.480 \pm 0.106$ & $0.205 \pm 0.042$ & $0.378 \pm 0.101$ \\
\hline & $50 \%$ & $0.289 \pm 0.062$ & $0.434 \pm 0.100$ & $0.183 \pm 0.040$ & $0.331 \pm 0.094$ \\
\hline & $60 \%$ & $0.286 \pm 0.064$ & $0.398 \pm 0.092$ & $0.164 \pm 0.037$ & $0.303 \pm 0.091$ \\
\hline & $70 \%$ & $0.288 \pm 0.066$ & $0.369 \pm 0.090$ & $0.151 \pm 0.036$ & $0.293 \pm 0.087$ \\
\hline & $80 \%$ & $0.290 \pm 0.067$ & $0.354 \pm 0.089$ & $0.144 \pm 0.035$ & $0.272 \pm 0.082$ \\
\hline & $90 \%$ & $0.279 \pm 0.067$ & $0.337 \pm 0.083$ & $0.138 \pm 0.033$ & $0.234 \pm 0.080$ \\
\hline & $100 \%$ & $0.250 \pm 0.061$ & $0.299 \pm 0.072$ & $0.134 \pm 0.031$ & $0.230 \pm 0.076$ \\
\hline
\end{tabular}

平均值 \pm 標準誤差. $\mathrm{H} 0^{\circ}$ : 股関節角度 $0^{\circ}, \mathrm{H} 90^{\circ}$ : 股関節角度 $90^{\circ}, \mathrm{K} 30^{\circ}$ : 膝関節角度 $30^{\circ}, \mathrm{K} 90^{\circ}$ : 膝関節角度 $90^{\circ}$. $\mathrm{MC}: \mathrm{MC}$ センサー, $\mathrm{VMO}$ ：内側広筋斜頭, $\mathrm{VL}$ ：外側広筋, $\mathrm{RF}$ ：大腿直筋。* : 同一股関節角度に抢ける膝関節角度の 違いによる有意差 $(\mathrm{p}<0.05)$, \# : 同一膝関節角度に扔ける股関節角度の違いによる有意差.

における等尺性収縮時の膝伸展筋群および膝蓋腱の力学 的活動について検討した。その結果, MC センサー法で 計測した形状変化量は, 股関節屈曲位の RFを除いて, トルクの高強度局面で股関節角度に関係なく膝関節屈曲 位よりも軽度屈曲位で有意に高い值を示した。一方，筋 放電量は, 膝関節屈曲位が軽度屈曲位よりも高かったこ
とから，膝関節角度が筋の活動動態に及ぼす影響が，筋 放電量と形状変化量では異なることが明らかとなった。 また, PT の形状変化量の最大值は $20 \% \mathrm{MVC} て ゙$ 認めら れ，膝関節屈曲位に対して軽度屈曲位が有意に低い值を 示し, 膝蓋腱の形状（撓み）が影響しているものと考え られた。 
トルク測定の結果，股関節角度の違いによるピークト ルクの差は認められなかったが, 膝関節角度の違いに よって有意な差が確認された. Pinciveroら 10)や Babault ら 19) は，膝伸展トルクは股関節角度が一定の場 合, 膝関節角度屈曲位が軽度屈曲位よりも高いことを報 告している。本研究でも膝関節屈曲位のピークトルクが 軽度屈曲位よりも高く, 先行研究 10,19) を支持する結果 となった。筋放電量は, 神経 - 筋レベルにおける運動単 位の動員や発射頻度を定量化したものであり，活動筋の 収縮力を次第に強めていくことで高くなる 10). 本研究 でも，全ての姿勢でトルク強度に伴う筋放電量の増大が みられた。また，VMO，VLおよび股関節屈曲位の RF の筋放電量は, 膝関節屈曲位が軽度屈曲位よりも高く, トルクの大小に影響したものと考えられた。一方，股関 節伸展位では RF の筋放電量に膝関節角度の影響が認め られなかった。これらの結果から，二関節筋である $\mathrm{RF}$ は股関節が伸張した状態では膝関節角度を变化させても 筋放電量の差を生じさせる程の影響が認められないこと が推察された。この結果は, 筋活動レベルの関節角度依 存性が協働筋間で異なることを指摘した先行研究 10,20) を支持するものであった．

$\mathrm{MC}$ センサー法で計測した筋の形状変化量は，いずれ の姿勢においてもトルク強度に伴い増大した。この結果 は, 上腕二頭筋を対象としたĐorđević ら 13,14)の報告と 同様であった，本研究ではVMO, VLおよび股関節伸 展位の RF では，膝関節角度による形状変化量の差が認 められたが, 股関節屈曲位の RF では膝関節角度による 有意差は認められなかった。また, RF のみ $30 \% \mathrm{MVC}$ から $60 \% \mathrm{MVC}$ の間に股関節角度の影響が認められた。 VMO およびVLとRFによる結果の相違は, 両関節角 度の变化による各筋の筋長変化の度合いが影響したもの と推察される。すなわち, 単関節筋である VMO や VL は, いずれの股関節角度においても, 筋長に及ぼす膝関 節角度の影響が同程度であるのに対して，二関節筋であ る $\mathrm{RF}$ は，膝関節の伸展動作だけでなく股関節の屈曲動 作にも関与 21) するため, 筋長の変化度合いが大きかっ たものと推察される。 また, 股関節屈曲位における RF の筋長は力 - 長さ関係の上行脚の範囲に相当しており, 膝関節角度が変化してもその範囲はさほど変化せず, 形 状変化量の有意差が認められなかったものと推察され る. 本研究の結果から, 膝関節伸展運動における膝伸展 筋群の形状变化量は, 膝関節および股関節角度の影響を 受けるが，その影響は各筋によって異なることが示唆さ れた。

本研究で注目すべき点は, 筋放電量は軽度屈曲位より も屈曲位で高かったのに対して, 形状変化量は屈曲位よ りも軽度屈曲位で高い值を示したことである。形状変化 量が膝関節軽度屈曲位で高い值を示した理由として次の ことが考えられる。まず，外側広筋のような羽状筋の場
合, 膝関節の伸展に伴い筋は収縮し, 羽状角が増大する ことで筋の生理学的横断面積が大きくなり筋張力が増大 する 1,12)。また，筋線維はその長軸方向に張力を発揮す るため, 羽状角の大きい膝関節軽度屈曲位では屈曲位よ りも筋線維の長軸方向が, 皮膚上に貼付したセンサーに 対してより垂直に近い状態となる。したがって，膝関節 軽度屈曲位では, 膝伸展筋群の生理学的断面積と羽状角 の増加によって形状変化量の值が高值を示したものと推 察された。また，MCセンサー法は，筋電図法による筋 活動レベルの評価とは異なり，筋の形状を加味した活動 動態を評価する指標として活用できる可能性が示唆さ れた。

PT の形状変化量は, トルクの $20 \% \mathrm{MVC}$ で最大とな り，その後は収縮強度に伴って低下した. Ichinose ら 12) は，トルクに起因する腱の長さおよび角度の変化は, よ り低い力レベル $(30 \% \mathrm{MVC})$ で大きいことを指摘して おり，本研究の結果はそれと類似していた。また，PT の形状変化量の最大值は，K30よりも K90の方が高 かった。これは表 1 に示したように, PT は膝関節屈曲 位よりも軽度屈曲位で撓んだ形状であったことが影響し たものと考えられる。 $\mathrm{PT}$ は，膝伸展筋群の収縮力を脛 骨に伝える役割を担っているため, 膝関節軽度屈曲位で は, 膝伸展筋群で生み出された収縮力が PT の撓みに よって吸収され，その力が効率よく脛骨に伝達されな かった22)ものと推察された.

従来, ヒト生体内における膝蓋腱の力学的特性は超音 波法による矢状面の画像から，筋の収縮によって生じる 腱の伸張量を計測し，その伸張量と張力の関係から弾性 特性（剛性や弾性係数）を推定することで評価されてき た. 膝蓋腱は膝伸展筋群の収縮力を脛骨に伝達する役割 を担っており, これらの力学的特性はその力の伝達効率 の指標となりうるものである。しかし，Defrateら 23)は， 異なる膝関節角度における自荷重時の膝蓋腱の動態を 3 次元的に観察したところ, 膝関節伸展位から屈曲位にか けて, 膝蓋腱は矢状面上に前傾から後傾し, 冠状面上に 内傾から外傾方向へと変動することを明らかにした。こ れは, PT が連結する膝蓋骨の変動を示すものである. また, 膝蓋骨は膝関節屈曲位で後傾し, 大腿骨顆間構内 にかみ合った状態 24,25) となることで膝関節の安定性を 保つ。ささに，膝伸展運動では内側広筋斜頭が，滕蓋骨 の外側偏位を抑止するための役割を持っており，膝関節 の安定性を保つために機能するという 18,26,27). これら の指摘から, 正常な運動や効率の良い動作を生み出すた めには，筋や腱の各機能によって膝関節の安定性が保た れているものと考えられる。実際に，膝関節の不安定性 は，身体運動の制限や他の障害を引き起こす要因となり うるものである。本研究の結果は, 臨床現場などで膝関 節運動に制限がある場合に対して，効率的な訓練の姿勢 を検討する際に応用できる，例えば，膝関節屈曲位での 
膝伸展運動は, 膝伸展筋群の筋放電量や膝蓋腱の活動を 高めるのに対して有効であり，膝関節軽度屈曲位では膝 蓋腱に大きな負担をかけることなく運動を実施すること ができる.

$\mathrm{MC}$ センサー法は非侵襲的かつ簡便な手法によって筋 および腱の力学的活動を評価 13,14,16)できるため, 臨床 現場のみならずスポーツ選手のトレーニングやコンディ ショニングの場にも活用できるものと考えられる。しか し， MC センサー法で計測する形状変化量は, 対象者の 脂肪厚，筋厚および皮膚の伸長率による影響があるもの と予想される。今後は, MC七ンサー法の信頼性をより 獲得するために, 脂肪厚といった形態的要素の影響や, 腱を対象とした検証実験を継続する必要性がある。

最後に, MC センサー法で計測した膝伸展筋群および 膝蓋腱の形状変化量は, 膝関節角度によって变化した筋 や腱の形状を反映した活動動態を示すものであり，トル クの推定のみならず，滕伸展筋群と膝蓋腱の機能を評価 する指標として活用できる可能性が示唆された。

利益相反 本研究に関し，開示すべき利益相反はない.

\section{引用文献}

1) Fukunaga $T$, Ichinose $Y$, Ito $M$, et al.: Determination of fascicle length and pennation in a contracting human muscle in vivo. $\mathrm{J}$ Appl Physiol 1985, 1997, 82: 354-358.

2) 山本憲隆, 高辻勇貴 : ヒト膝蓋腱および前十字勒帯の力学 的性質と大腿四頭筋筋力の関係. 日本機械学会論文集 A 編, 2012, 78: 361-369.

3) Onambélé GN, Burgess K, Pearson SJ: Gender-specific in vivo measurement of the structural and mechanical properties of the human patellar tendon. J Orthop Res, 2007, 25: 16351642 .

4) Pearson SJ, Mohammed AS, Hussain SR: Patellar tendon in vivo regional strain with varying knee angle. J Biomech, 2017, 61: 45-50

5) Malliaras P, Kamal B, Nowell A, et al.: Patellar tendon adaptation in relation to load-intensity and contraction type. J Biomech, 2013, 46: 1893-1899.

6) Kongsgaard M, Reitelseder S, Pedersen TG, et al.: Region specific patellar tendon hypertrophy in humans following resistance training. Acta Physiol (Oxf), 2007, 191: 111-121.

7) Yamamoto N, Ota T: Relationships between the mechanical properties of patellar tendons and quadriceps strength in humans. J Biomech Sci Eng, 2009, 4: 530-538.

8) Kubo K, Ikebukuro T, Yaeshima K, et al.: Effects of static and dynamic training on the stiffness and blood volume of tendon in vivo. J Appl Physiol 1985, 2009, 106: 412-417.

9) Seynnes OR, Bojsen-Møller J, Albracht K, et al.: Ultrasoundbased testing of tendon mechanical properties: a critical evaluation. J Appl Physiol 1985, 2015, 118: 133-141.

10) Pincivero DM, Salfetnikov Y, Campy RM, et al.: Angle- and gender-specific quadriceps femoris muscle recruitment and knee extensor torque. J Biomech, 2004, 37: 1689-1697.

11) Herzog W, Hasler E, Abrahamse SK: A comparison of knee extensor strength curves obtained theoretically and experimentally. Med Sci Sports Exerc, 1991, 23: 108-114.

12) Ichinose $Y$, Kawakami $Y$, Ito $M$, et al.: Estimation of active force-length characteristics of human vastus lateralis muscle. Acta Anat (Basel), 1997, 159: 78-83.

13) Đorđević S, Stančin S, Meglič A, et al.: MC sensor--a novel method for measurement of muscle tension. Sens Basel, 2011, 11: 9411-9425.

14) Đorđević S, Tomažič $S$, Narici $M$, et al.: In-vivo measurement of muscle tension: dynamic properties of the MC sensor during isometric muscle contraction. Sens Basel, 2014, 14: 17848-17863.

15) Mohamad NZ, Hamzaid NA, Davis GM, et al.: Mechanomyography and torque during FES-evoked muscle contractions to fatigue in individuals with spinal cord injury. Sens Basel, 2017, 17: 1627-1641.

16) Đorđević S, Berdajs M, Modic Ž, et al.: Preliminary force load analysis of the knee muscle-tendon complex between squatting with MC sensor. ISOT, Rome, 2014, pp23-27.

17) Fredberg U, Bolvig L, Andersen NT, et al.: Ultrasonography in evaluation of Achilles and patella tendon thickness. Ultraschall Med, 2008, 29: 60-65.

18) 谷埜予士次, 大工谷新一, 鈴木俊明：膝伸展疲労課題中の 内側広筋斜頭および長頭の機能に関する筋電図学的検討. 体力科学, 2009, 58: 441-452.

19) Babault N, Pousson M, Michaut A, et al.: Effect of quadriceps femoris muscle length on neural activation during isometric and concentric contractions. J Appl Physiol 1985, 2003, 94: 983-990.

20) 江間諒一, 若原 卓, 金久博昭・他：股関節抢よび膝関節 角度が等尺性膝関節伸展卜ルクと大腿四頭筋の筋活動に与 える影響. スポーツ科学研究, 2010, 7: 109-118.

21) 金子公宥:改定スポーツ・バイオメカニクス入門. 杏林書院, 東京, 1994, pp14-23.

22) 瀧下 渡, 竹中 睦, 長岡大地 - 他 : 収縮時の筋束動態か らみた関節角度一トルク関係. 理学療法科学, 2015, 30: 803-809.

23) Defrate LE, Nha KW, Papannagari R, et al.: The biomechanical function of the patellar tendon during in-vivo weightbearing flexion. J Biomech, 2007, 40: 1716-1722.

24) Merican AM, Amis AA: Iliotibial band tension affects patellofemoral and tibiofemoral kinematics. J Biomech, 2009, 42: 1539-1546.

25) Csintalan RP, Schulz MM, Woo J, et al:: Gender differences in patellofemoral joint biomechanics. Clin Orthop Relat Res, 2002, (402): 260-269.

26) 生田啓記, 井尻朋人, 鈴木俊明：膝関節屈曲角度の変化に 伴う膝関節伸展等尺性収縮時の大腿四頭筋における筋活動 変化. 理学療法科学, 2016, 31: 7-11.

27) Travnik L, Pernus F, Erzen I: Histochemical and morphometric characteristics of the normal human vastus medialis longus and vastus medialis obliquus muscles. J Anat, 1995, 187: 403411. 